\title{
PENGABDIAN KEPADA MASYARAKAT PENDIDIKAN KESEHATAN BANTUAN HIDUP DASAR
}

\author{
Widyanata, Komang Agus Jerry ${ }^{1 *}$; Wijaya, I Made Sukma ${ }^{1}$; Widayati, Kurniasih ${ }^{1}$ \\ ${ }^{1}$ Akademi Keperawatan Kesdam IX/Udayana \\ *Korespondensi: jerrywidyanata@yahoo.com
}

\begin{abstract}
Background: Every two minutes one person dies of cardiac arrest. death rates can be prevented if the victim gets immediate assistance, if someone who is trained in pulmonary cardiac resuscitation (CPR) provides basic life support until medical assistance takes over. Basic life support can be done by anyone and anywhere as soon as possible at the beginning of the occurrence of cardiac arrest to increase survival. This activity aims to provided health education to the community so that they can know and demonstrate how to provide basic life support in cases of cardiac arrest. Methods: Health education uses the lecture method of discussion accompanied by demonstration with power point media which is assisted with LCD and projector for 30 minutes then followed by demonstration using CPR manikin (Cardiopulmonary Resuscitation) for 10 minutes. A sample size of 30 people in $\mathrm{Br}$. Tek-Tek, Desa Peguyangan, Denpasar Utara with accidental sampling technique. Results: The minimum results achieved are $80 \%$ at the point of practicing how to provide pulmonary heart resuscitation and a value of $100 \%$ is at 2 points of each evaluation which mentions the meaning of basic life support and mentions the steps of basic life support, while for indications and contraindications from basic life support $90 \%$ of participants were able to mention it. Conclusion: Health education program activities and demonstrations about basic life support that have been implemented are very useful to increase knowledge and are expected to be able to practice and provide first aid in cases of respiratory arrest and cardiac arrest.
\end{abstract}

Keywords: BLS; CPR; Fist aid

\begin{abstract}
ABSTRAK
Latar belakang: Setiaap dua menit terdapat satu orang meninggal karena penyakit henti jantung. Kematian karena henti jantung dan henti nafas dapat dicegah bila korban mendapatkan bantuan segera, jika seseorang yang terlatih resusitasi jantung paru (RJP) memberikan bantuan hidup dasar sampai dengan bantuan medis mengambil alih. Bantuan hidup dasar dapat dilakukan oleh siapapun dan dimanapun sesegera mungkin disaat awal terjadinya henti jantung untuk meningkatkan angka kelangsungan hidup. Tujuan kegiatan ini adalah memberikan pendidikan kesehatan kepada masyarakat agar dapat mengetahui dan mendemonstrasikan cara pemberian bantuan hidup dasar pada kasus henti jantung. Metode: Pendidikan kesehatan diberikan kepada masyarakat desa Br. Tek-Tek, Desa Peguyangan, Denpasar Utara sebanyak 30 orang dengan pemilihan sampel secara accidental menggunakan metode ceramah diskusi disertai demonstrasikan dengan media power point yang dibantu dengan LCD dan proyektor selama 30 menit kemudian dilanjutkan demonstrasi menggunakan manekin CPR
\end{abstract}


(Cardiopulmonary Resuscitation) selama 10 menit. Hasil: Hasil minimal yang dicapai adalah $80 \%$ pada poin mempraktikkan cara memberikan resusitasi jantung paru dan nilai $100 \%$ ada pada 2 poin evaluasi masing-masing yaitu menyebutkan arti dari bantuan hidup dasar dan menyebutkan langkah-langkah dari bantuan hidup dasar, sedangkan untuk menyebutkan indikasi dan kontraindikasi dari bantuan hidup dasar didapatkan 90\% peserta mampu menyebutkannya. Simpulan: Program kegiatan pendidikan kesehatan dan demonstrasi tentang BHD yang telah dilaksanakan sangatkan bermanfaat untuk meningkatkan pengetahuan masyarakat tentang BHD itu sendiri sehingga diharapkan juga akan mampu mempraktikkan dan memberikan pertolongan pertama pada kasus henti nafas dan henti jantung.

Kata kunci: BHD; Pertolongan pertama; RJP

\section{PENDAHULUAN}

American Heart Association atau AHA (2010) mencatat bahwa setiap dua menit terdapat satu orang meninggal karena penyakit henti jantung mendadak (HJM). Berdasarkan laporan dari Centers for Disease Control and Prevention (CDC) yang melakukan survei terhadap kejadian cardiac arrest di United States selama periode 1 Oktober 2005 sampai 31 Desember 2010 didapatkan sekitar 31,689 kasus cardiac arrest di luar rumah sakit. Kejadian tersebut ditemukan sejumlah 33,3\% dari kasus memperoleh bantuan CPR dari orang awam dan hanya 3,7\% mendapatkan bantuan automated external defibrillator (AED) sebelum personal EMS datang (Bryan et al, 2011). Berdasarkan hasil Riset Kesehatan Dasar (RISKESDAS) tahun 2007 di Indonesia hanya disebutkan prevalensi nasional penyakit jantung sebesar 7,2\% (Subagjo dkk, 2011).

Penyebab henti jantung atau serangan jantung secara umum dikarenakan oleh aritmia jantung khususnya fibrilasi ventrikel, sumbatan jalan nafas karena benda asing, tenggelam, stroke/ CVA, overdosis obat-obatan, tercekik, trauma inhalasi, tersengat listrik, reaksi alergi yang hebat (anafilaksis), trauma hebat misalnya kecelakaan kendaraan bermotor dan keracunan (Berg, 2010). Hal ini menyebabkan kurangnya oksigen yang dapat disalurkan ke seluruh tubuh terutama otak dan jantung itu sendiri. Bila kurang oksigen ke otak, maka sel-sel otak akan mati dan hilangnya kesadaran dan fungsi otak lainnya. Pada jantung, sel-sel jantung akan kekurangan oksigen dan mati. Sel-sel yang telah mati tidak dapat dihidupkan kembali. Bila tidak cepat di tangani, maka dapat berujung pada kematian (Indonesia Heart Association, 2013; Subagjo dkk, 2011). 
Kematian karena henti jantung dan henti nafas dapat dicegah bila korban mendapatkan bantuan segera, jika seseorang yang terlatih resusitasi jantung paru (RJP) memberikan bantuan hidup dasar sampai dengan bantuan medis mengambil alih. Bantuan hidup dasar dapat dilakukan oleh siapapun dan dimanapun sesegera mungkin disaat awal terjadinya henti jantung untuk meningkatkan angka kelangsungan hidup (Suharsono dan Ningsih, 2009; Subagjo dkk, 2011).

Berdasarkan uraian diatas henti jantung dan henti nafas merupakan kasus kegawatan yang memerlukan tindakan segera seperti BHD untuk mencegah kematian. Pendidikan dan pelatihan bantuan hidup dasar penting diberikan kepada masyarakat untuk dapat meningkatkan angka kelangsungan hidup bagi pasien atau korban yang mengalami henti jantung.

\section{METODE}

Kegiatan pengabdian kepada masyarakat ini telah dilaksanakan pada hari Kamis tanggal 28 Januari 2016 di Br. Tek-Tek, Desa Peguyangan, Denpasar Utara pada pukul 19.00 wita. Pendidikan kesehatan dalam pengabdian masyarakat ini telah berlangsung dengan baik menggunakan metode ceramah diskusi disertai dengan demonstrasi. Metode ceramah dilakukan dengan menggunakan power point yang dibantu dengan LCD dan proyektor di depan masyarakat selama 30 menit kemudian dilanjutkan demonstrasi menggunakan manekin Cardiopulmonary Resuscitation (CFR) selama 10 menit dan terakhir dilakukan tanya jawab/diskusi serta diberikan kesempatan masyarakat untuk mempraktikkannya sendiri.

\section{HASIL DAN PEMBAHASAN}

Kegiatan pengabdian masyarakat dengan memberikan pendidikan kesehatan bantuan hidup dasar pada masyarakat Br. Tek-Tek, Peguyangan, Kecamatan Denpasar Utara telah berlangsung baik. Kegiatan ini dimulai dari persiapan yang dimulai pada pukul 18.00 wita di Balai Banjar Tek-Tek, Desa Peguyangan dan pada pukul 19.00 wita masyarakat datang sesuai waktu yang telah ditentukan.

Pertama kali dilakukan pengisian daftar hadir dan diberikan snack lalu acara dibuka oleh kepala lingkungan atau kelian adat dan dinas pada pukul 19.15 wita. 
Kegiatan telah berlangsung selama satu jam dan jumlah peserta yang hadir sebanyak 30 orang. Beberapa masyarakat khususnya kepala keluarga tidak bisa hadir seluruhnya oleh karena ada yang bekerja dan persiapan piodalan yang bersamaan dengan kegiatan pengabdian masyarakat akan tetapi seluruh kegiatan tetap berjalan lancar. Pada akhir kegiatan kembali ditutup oleh kepala lingkungan dan ucapan terima kasih dari tim pengabdian masyarakat Akper Kesdam IX/Udayana.

Tahap akhir pengabdian masyarakat dilakukan evaluasi untuk mengetahui pencapaian tujuan yang telah ditentukan. Setelah diberikan ceramah, diskusi dan demonstrasi bantuan hidup dasar maka dilakukan evaluasi kemudian diakhiri dengan pemberian leaflet bantuan hidup dasa. Teknik evaluasi dilakukan secara lisan dengan menanyakan langsung kepada peserta dan evaluasi dengan cara praktik yang dilakukan oleh peserta. Evaluasi pada kegiatan pendidikan kesehatan tentang bantuan hidup dasar yang diberikan pada masyarakat di Br. Tek-Tek, Desa Peguyangan, Kecamatan Denpasar Utara sebagai berikut:

Tabel 1. Hasil evaluasi kegiatan pendidikan kesehatan tentang bantuan hidup dasar yang diberikan pada masyarakat di Br. Tek-Tek, Desa Peguyangan, Kecamatan Denpasar Utara.

\begin{tabular}{cll}
\hline No & \multicolumn{1}{c}{ Evaluasi } & Hasil \\
\hline 1 & Menyebutkan arti dari bantuan hidup dasar & $100 \%$ \\
2 & Menyebutkan indikasi dan kontraindikasi dari bantuan hidup dasar & $90 \%$ \\
3 & Menyebutkan langkah-langkah dari bantuan hidup dasar & $100 \%$ \\
4 & $\begin{array}{l}\text { Mempraktikkan cara memberikan resusitasi jantung paru pada } \\
\text { orang dewasa dalam bantuan hidup dasar. }\end{array}$ & $80 \%$ \\
\hline
\end{tabular}

Berdasarkan tabel diatas menunjukkan hasil minimal yang dicapai adalah $80 \%$ pada poin mempraktikkan cara memberikan resusitasi jantung paru pada orang dewasa dalam bantuan hidup dasar dan nilai $100 \%$ ada pada 2 poin evaluasi masingmasing yaitu menyebutkan arti dari bantuan hidup dasar dan menyebutkan langkahlangkah dari bantuan hidup dasar, sedangkan untuk menyebutkan indikasi dan kontraindikasi dari bantuan hidup dasar didapatkan $90 \%$ peserta mampu menyebutkannya.

Berdasarkan rata-rata nilai evaluasi menunjukkan bahwa tingkat keberhasilan kegiatan pengabdian masyarakat pendidikan kesehatan tentang bantuan hidup dasar yang diberikan pada masyarakat di Br. Tek-Tek, Desa 
Peguyangan sebanyak 92,5\%. nilai tersebut menunjukkan bahwa program kegiatan ini berhasil. Hal ini tidak terlepas dari metode pembelajaran yang digunakan dimana dalam melaksanakan kegiatan ini selain menggunakan metode ceramah juga menggunakan media presentasi. Menurut Daryanto (2013) menyatakan bahwa pemilihan media presentasi yang disajikan berupa teks, gambar serta animasi yang dikombinasikan mampu menarik perhatian dari responden dalam melaksanakan pendidikan kesehatan sehingga dapat meningkatkan pengetahuan responden.

Pada saat pelaksanaan kegiatan, responden terbilang baru mendapatkan pendidikan kesehatan menggunakan media presentasi dan demonstrasi sehingga responden memiliki keingintahuan besar dan sangat antusias. Media pembelajaran mampu mempengaruhi efektivitas pembelajaran sehingga mampu meningkatkan peserta didik dalam belajar dan mampu membantu meningkatkan penyerapan materi dan memfokuskan informasi pengetahuan (Arsyad, 2006).

\section{SIMPULAN}

Henti nafas dan henti jantung adalah kondisi kegawatdaruratan yang membutuhkan penanganan yang segera seperti bantuan hidup dasar (BHD), apabila tidak segera di tangani akan menyebabkan kematian. Peran serta masyarakat dalam mencegah kematian yang disebabkan oleh henti nafas dan henti jantung sangat penting mengingat kasus tersebut paling umum ditemukan di tengah-tengah masyarakat dimana dan kapan saja, maka sangat perlu bagi masyarakat umum untuk mengetahui cara penanganan segera seperti bantuan hidup dasar (BHD). Program kegiatan pendidikan kesehatan dan demonstrasi tentang BHD yang telah dilaksanakan sangatkan bermanfaat untuk meningkatkan pengetahuan masyarakat tentang BHD itu sendiri sehingga diharapkan juga akan mampu mempraktikkan dan memberikan pertolongan pertama pada kasus henti nafas dan henti jantung, dengan demikian angka kematian yang disebabkan oleh kasus henti nafas dan henti jantung dapat berkurang.

\section{UCAPAN TERIMAKASIH}

Terima kasih penulis ucapkan kepada Akper Kesdam IX/Udayana atas dukungan dana yang telah diberikan untuk melaksanakan kegiatan ini. 


\section{DAFTAR PUSTAKA}

American Heart Association (AHA). 2010. Adult Basic Life Support: Guidelines for Cardiopulmonary Resuscitation and Emergency Cardiovascular Care.(http://circ.ahajournals.org/content/122/18_suppl_3/S685.full.pdf $+\mathrm{html}$ diakses 4 Januari 2016).

Berg, RA., Chair, Hemphill, R.,Abella BS., Aufderheide, TP., Cave, DM., Hazinki, Mf., Lerner, EB., Rea, TD.,Sayre, MR., Swor, RA., 2010 American Heart Association Guidelines for Cardiopulmonary Resuscitation and Emergency Cardiovascular Care, (online), (http://circ.ahajaurnals.org/content/122/18 suppl3/s685.full).

Bryan., et al. (2011). Out-of-hospital cardiac arrest surveillance — cardiac arrest registry to enhance survival (CARES), united states. Morbidity and Mortality Weekly Report Surveillance Summaries / Vol. 60 / No. 8.

Arsyad, A. (2011). Media Pembelajaran cetakan ke-15.Jakarta : rajawali Pers

Subagjo, A., Achyar, Ratnaningsih, E., Sugiman,T., Kosasih, A., Agustinus, R.(2011). Buku Panduan Kursus Bantuan Hidup Jantung Dasar. Jakarta:Perhimpunan Dokter Spesialis Kardiovaskular Indonesia.

Suharsono, T dan Ningsih, DK. 2008. Penatalaksanaan Henti Jantung Diluar Rumah Sakit. Malang: UMM Press

Indonesia Heart Association. 2015. Henti Jantung. (Online). (http://www.inaheart.org/education for_patient/2015/5/7/henti_jantung, di akses pada tanggal 4 Januari 2015) 